\title{
ANALISIS KELIMPAHAN DAN DISTRIBUSI LARVA IKAN DI PERAIRAN PESISIR LAMPUNG TIMUR
}

\author{
La Ode Syahlan S. Sagala ${ }^{a} *$, Mohammad Mukhlis Kamal ${ }^{a, b}$, Zairion ${ }^{\text {b }}$ \\ ${ }^{a}$ Program Studi Pengelolaan Sumberdaya Perairan, Sekolah Pascasarjana, Fakultas Perikanan dan Ilmu \\ Kelautan, Institut Pertanian Bogor, Jl. Agatis Kampus IPB Dramaga, Bogor, Indonesia 16680 \\ ${ }^{\mathrm{b}}$ Departemen Manajemen Sumberdaya Perairan, Fakultas Perikanan dan Ilmu Kelautan, Institut Pertanian \\ Bogor, Jl. Agatis Kampus IPB Dramaga, Bogor, Indonesia 16680 \\ * Koresponden penulis : atho.sagala92@gmail.com
}

\begin{abstract}
Abstrak
Studi iktioplankton mengenai kelimpahan dan distribusi larva ikan di perairan pesisir Lampung Timur hingga saat ini informasinya sangat terbatas. Penelitian ini bertujuan untuk meningkatkan pengetahuan tentang stadia awal kehidupan organisme dan bermanfaat dalam mengelola keanekaragaman serta sumberdaya hayati di perairan. Penelitian ini merupakan representasi musim timur (Bulan Juni) dan musim peralihan (Bulan September) di Tahun 2017. Pengambilan larva menggunakan alat bonggo-net sedangkan identifikasi larva menggunakan alat Dino-lite. Hasil penelitian menunjukkan bahwa kelimpahan larva ikan pada musim timur $\left(2.990 \mathrm{ind} / \mathrm{m}^{3}\right)$ lebih tinggi dibandingkan musim peralihan $\left(1.902 \mathrm{ind} / \mathrm{m}^{3}\right)$. Berdasarkan periode kedua musim pengamatan, komposisi larva ikan tercatat 81 famili, terdapat 10 famili dominan yaitu Gobiidae $(11 \%)$ merupakan famili larva yang mendominasi di periode kedua musim pengamatan diikuti Pegasidae (10\%), Mullidae (9\%), Pomacentridae (7\%), Sillaginidae (4\%), Bleniidae (4\%), Bythitidae (3\%), Carangidae (3\%), Pseudochromidae (3\%) dan Bothidae (2\%) sedangkan distribusi larva ikan di sektor perairan pinggir (238 individu) lebih tinggi dibandingkan perairan tengah (156 individu) dan perairan luar (113 individu). Adapun tahap stadia larva ikan menunjukkan Flexion memiliki persentase tertinggi diikuti post-flexion dan pre-flexion. Parameter suhu, salinitas dan $\mathrm{pH}$ menunjukkan keadaan kisaran optimal kelangsungan hidup dan pertumbuhan larva ikan, kecerahan dan kekeruhan sesuai standar baku mutu air, kecepatan arus musim timur (arus sangat cepat) dan musim peralihan (arus cepat hingga cepat) sedangkan fitoplankton dan zooplankton menunjukkan ketersediaan makanan alamiah yang cukup bagi kehidupan larva ikan. Hasil CCA menunjukkan konektivitas kelimpahan dan distribusi larva ikan memperlihatkan parameter kecerahan membentuk proyeksi titik sedangkan parameter kondisi lingkungan perairan lainnya membentuk proyeksi vektor terhadap periode kedua musim. Kelimpahan dan distribusi larva ikan di perairan pesisir Lampung Timur di ketiga sektor perairan memiliki proporsionalitas terhadap parameter kondisi lingkungan perairan terutama parameter arus dan perbedaan periode musim.
\end{abstract}

Kata Kunci: Distribusi, Kelimpahan, Kondisi Lingkungan Perairan

\begin{abstract}
The study of Ichthyoplankton on the abundance and distribution of fish larvae in coastal waters of East Lampung is currently very limited information. The research aims to improve the knowledge of the early life of organisms and is beneficial in managing diversity and biological resources in the waters. The research was the liquid representation of the eastern monsoon (June) and the transitional monsoon (September) in the year 2017. The uptake of larvae using the Bonggo-net tool while identifying larvae using the Dino-Lite tools. Research results that the abundance of fish larva in the eastern monsoon $\left(2.990 \mathrm{ind} / \mathrm{m}^{3}\right)$ is higher than the transitional monsoon $\left(1.902 \mathrm{ind} / \mathrm{m}^{3}\right)$. Based on the second period of observation monsoon, the composition of fish larva recorded 81 families, there are 10 dominant family of Gobiidae (11\%) Is the dominant larva family in the second period of the observation monsoon followed by Pegasidae $(10 \%)$, Mullidae (9\%), Pomacentridae (7\%), Sillaginidae (4\%), Bleniidae (4\%), Bythitidae (3\%), Carangidae (3\%), Pseudochromidae $(3 \%)$ and Bothidae $(2 \%)$ While the distribution of fish larvae in the edge waters sector (238 individuals) is higher than the middle water (156 individuals) and outer waters (113 individuals). As for stage stadia fish larvae show Flexion has the highest percentage followed post-flexion and pre-flexion. Temperature, salinity and $\mathrm{pH}$ parameters show optimum range of survival and growth of fish larva, brightness and turbidity in accordance with water quality standard standards, Eastern daylight flow rate (very fast current) and transitional monsoon (fast current to fast) while phytoplankton and zooplankton
\end{abstract}


show sufficient natural food availability for the life of fish larvae. The CCA results show the abundance of connectivity and distribution of fish larvae showing the brightness parameters forming a point projection while other water environmental conditions parameters form a vector projection against the second period of the monsoon. The abundance and distribution of fish larvae in coastal waters of East Lampung in all three sectors of the water has proportionality to the parameters of environmental conditions, especially the current parameters and the difference of the monsoon period.

Keywords: Abundance, Distribution, Water Environment Condition

\section{PENDAHULUAN}

Perairan pesisir Lampung Timur adalah perairan yang berhadapan langsung dengan laut jawa dan banyak ditemukannya berbagai jenis organisme didaerah habitatnya [1]. Karakteristik daerah ini merupakan perairan tipe pantai terbuka dan termasuk dalam wilayah pengelolaan Perikanan Negara Republik Indonesia (WPP-NRI 712) (Permen KP No.01 Tahun 2009) serta dikenal sebagai salah satu produser jenis organisme kepiting rajungan yang berpotensi di Indonesia. Hal ini dibuktikan hasil riset [2] tentang pengelolaan berkelanjutan perikanan Rajungan di perairan pesisir Lampung Timur.

Stadia larva pada ikan adalah tahap awal hidupan pasca menetas, umumnya bersifat planktonik sementara (meroplankton) dengan pergerakan dan distribusinya dipengaruhi oleh arus dan gelombang [3, 4]. Perkembangan morfologis larva ikan terbagi atas dua fase yaitu pro-larva, yang mengandung kuning telur, mulut dan rahang belum berkembang, bentuk tubuh transparan dan sedikit pigmen fungsinya belum diketahui, serta usus berbentuk tabung halus [5]. Pada fase ini, berdasarkan perkembangan tulang vertebrata bagian ekor, larva dikategorikan sebagai preflexion, flexion dan post-flexion [6], (2) fase post-larva, ditandai oleh hilangnya kuning telur, pigmen tubuh berwarna coklat dan mulai terbentuknya organ-organ tubuh yang baru serta mulai aktif berenang $[5,7,8]$.

Kelimpahan larva ikan merupakan hasil refleksi dari dinamika stok ikan [9] yaitu sebagai basis data daerah pemijahan, penilaian stok dan kekayaan biodervisitas hayati perairan serta pendugaan kondisi lingkungan perairan. Indeks kelimpahan disuatu perairan dapat dianalisis secara spasial dan temporal dikaitkan dengan kondisi fisika, kimia dan biologi perairan $[10,11,12]$.

Distribusi atau penyebaran larva ikan adalah pergerakan larva dari suatu tempat ketempat lain, baik secara horizontal maupun vertikal [13, 14, 15]. Penyebaran organisme merupakan informasi penting dalam menginterpretasikan karakteristik lingkungan pesisir dan laut, yang mana hal tersebut berimplikasi terhadap pendugaan indeks kelimpahan. Selain disebabkan arus dan gelombang, distribusi larva ikan di perairan menurut peneliti sebelumnya $[16,17]$ dipengaruhi oleh cahaya, suhu, salinitas, kedalaman, kekeruhan, kesuburan klorofil-a dan faktor biotik terutama predasi, kompetisi dan penyakit.

Kajian larva ikan di perairan Indonesia mengenai kelimpahan dan distribusi telah dilakukan pada beberapa tipologi perairan yakni di Teluk Palabuhanratu [18], Perairan Pulau Abang Galang Baru Batam [19], Perairan Teluk Ambon bagian dalam [20], Estuaria Pelawangan Timur [21], Estuari Sungai Musi [22], Laut Sulawesi [23], Teluk Cempi Nusa Tenggara Barat [24], Perairan estuari banjir kanal timur kota Semarang [25], Pulau Pramuka, Kepulauan Seribu Jakarta [26], Ekosistem Mangrove di Desa Pasar Banggi Kabupaten Rembang [27], Perairan Pantai Dukuh Bedono [28] dan Selat Alas Nusa Tenggara Barat (NTB) [29].

Riset mengenai stadia larva ikan di perairan pesisir Lampung Timur informasinya sangat terbatas dan sampai saat ini riset stadia larva difokuskan pada larva rajungan [30]. Berdasarkan hal tersebut, perairan pesisir Lampung Timur dipilih sebagai lokasi penelitian karena perairan ini dapat dianggap sebagai daerah pemijahan ikan dan memiliki karakteristik perairan yang khas sehingga diharapkan mampu memberikan interpretasi tentang kelimpahan larva, struktur ukuran dan tingkatan larva serta kondisi lingkungannya. Disamping itu, riset mengenai kelimpahan dan distribusi larva ikan di perairan ini masih belum banyak dilakukan dengan kata lain peneliti dapat dikategorikan sebagai riset perdana di perairan pesisir Lampung Timur. 


\section{BAHAN DAN METODE}

Pengambilan data penelitian dilakukan di perairan pesisir Lampung Timur pada tahun 2017, Waktu pengambilan sampel merupakan representasi periode musim timur (Bulan Juni) dan periode musim peralihan (Bulan September). Terdapat sembilan stasiun dalam pengambilan data penelitian yang terbagi dalam tiga sektor perairan dengan jarak tertentu dari garis pantai (Tabel 1 dan Gambar 1). Pengumpulan larva ikan dilakukan dalam resolusi horizontal sebagai gambaran distribusi larva ikan.

Tabel 1. Koordinat stasiun penelitian

\begin{tabular}{cccr}
\hline \multirow{2}{*}{ Stasiun } & \multirow{2}{*}{ Sektor } & \multicolumn{2}{c}{ Koordinat } \\
\cline { 3 - 4 } & & Lintang & Bujur \\
\hline ST3 & Perairan & $-5.3287^{\circ} \mathrm{LS}$ & $105,851^{\circ} \mathrm{BT}$ \\
ST4 & Pinggir & $-5.1643^{\circ} \mathrm{LS}$ & $105,883^{\circ} \mathrm{BT}$ \\
ST9 & $(<4$ mil) & $-5.0085^{\circ} \mathrm{LS}$ & $105,896^{\circ} \mathrm{BT}$ \\
\hline ST2 & Perairan & $-5.3277^{\circ} \mathrm{LS}$ & $105,933^{\circ} \mathrm{BT}$ \\
ST5 & Tengah & $-5.1636^{\circ} \mathrm{LS}$ & $105,974^{\circ} \mathrm{BT}$ \\
ST8 & $(4-10 \mathrm{mil})$ & $-5.0063^{\circ} \mathrm{LS}$ & $106^{\circ} \mathrm{BT}$ \\
\hline ST1 & Perairan & $-5.3016^{\circ} \mathrm{LS}$ & $106,058^{\circ} \mathrm{BT}$ \\
ST6 & Luar & $-5.1629^{\circ} \mathrm{LS}$ & $106,072^{\circ} \mathrm{BT}$ \\
ST7 & (>10 mil) & $-5.0024^{\circ} \mathrm{LS}$ & $106,093^{\circ} \mathrm{BT}$ \\
\hline
\end{tabular}

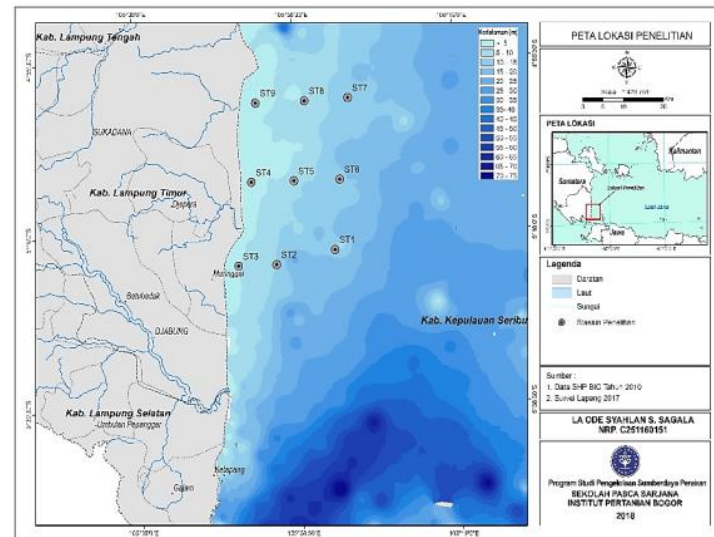

Gambar 1. Peta lokasi penelitian perairan pesisir Lampung Timur

\section{Pengambilan Larva dan Pengamatan Kondisi Lingkungan Perairan}

Dalam penelitian ini dilakukan dengan metode Purposive sampling pada setiap lokasi pengamatan, pertama kali mencatat koordinat sampling dengan menggunakan alat GPS. Kemudian sampel larva ikan dikumpulkan oleh Bonggo-net yang diameter bingkai mulut $60 \mathrm{~cm}$, panjang $3 \mathrm{~m}$ dan mata jaring $0,5 \mathrm{~mm}$ yang dilengkapi dengan flowmeter mekanis
(General Oceanics Seri 2030R), Bonggo-net diturunkan hingga pada posisi siap ditarik oleh kapal bermesin dengan kecepatan 1-2,5 knot. Saat on board, seluruh volume sampel yang tersaring dipisahkan dari sampah dan material abiotik lainnya kemudian dimasukkan kedalam botol sampel $500 \mathrm{ml}$ yang berisi larutan Etanol $96 \%$ dan diberi label. Pemisahan sampel larva ikan dari sampel organisme lainnya dilakukan di laboratorium Balai Riset Perikanan Laut, Kementerian Kelautan dan Perikanan, Cibinong Bogor.

Identifikasi pengamatan dan pengukuran morfometrik stadia larva ikan dilakukan di laboratorium Biologi Makro, Departemen Manajemen Sumberdaya Perairan, IPB. Pengukuran morfometrik larva ikan dilakukan dengan menggunakan alat mikroskop portabel Dino-Lite AM4113/AD4113 berketelitian $0,05 \mathrm{~mm}$. Setiap individu larva diindentifikasi hingga tingkat famili. Identifikasi larva ikan dilakukan dengan merujuk kepada buku identifikasi The Larvae of Indo-Pacific Coastal Fishes [31]. Kriteria identifikasi larva ikan berdasarkan panjang moncong ( $\mathrm{SnL}$ ), diameter mata (ED), panjang kepala (HL), panjang tubuh (BL), panjang antara ventral anal ke sirip anal (VAFL), panjang sirip depan anal (PAL), panjang bagian depan sirip punggung (PDL) dan lebar tubuh (BD).

Pengukuran kondisi lingkungan perairan yang meliputi parameter fisika, kimia dan biologi dilakukan setelah sampling larva selesai. Parameter fisika-kimia antara lain kecepatan arus menggunakan alat ADCP (Acoustic Doppler Current Profiler) dan kecerahan, suhu, $\mathrm{pH}$ serta salinitas diukur menggunakan alat CTD (Conductivity Temperature Depth) dan parameter biologi, pengukuran fitoplankton menggunakan jaring diameter $0,3 \mathrm{~m}$, panjang $1 \mathrm{~m}$, mesh size $80 \mu \mathrm{m}$ dan zooplankton diameter $0,45 \mathrm{~m}, 1,8 \mathrm{~m}$ dan mesh size $300 \mu \mathrm{m}$.

\section{Analisis Data}

Kelimpahan larva ikan didefinisikan banyaknya larva per satuan volume air yang dihitung dengan menggunakan rumus [32]

$$
N=\frac{n}{V_{t s r}}
$$


Notasi, $N$ merupakan kelimpahan larva ikan (ind $\left./ \mathrm{m}^{3}\right), \mathrm{n}$ adalah jumlah larva ikan tercacah (ind.), dan Vtsr adalah volume air tersaring $\left(\mathrm{m}^{3}\right)$ yang diperoleh melalui persamaan:

$$
V_{t s r^{\left(m^{3}\right)}}=3,14 x r^{2} x d
$$

$\mathrm{r}$ adalah jari-jari mulut jaring (m), d adaan jarak tarikan bonggo-net yang diperoleh persamaan:

$$
d(m)=\frac{\text { Selisih Rotor } x \text { Konstanta Rotor }}{999999}
$$

Konstanta rotor flowmeter mekanis seri 2030R adalah 26873. Selisih rotor adalah jumlah putaran rotor selama penarikan

\section{HASIL DAN PEMBAHASAN}

\section{Kelimpahan Larva Ikan}

Hasil pengumpulan larva ikan pada penelitian ini tercatat pada musim timur (Juni 2017) berkisar antara $0,114-0,692 \mathrm{ind} / \mathrm{m}^{3}$ dan pada musim peralihan (September 2017) antara $0,076-0,494 \mathrm{ind} / \mathrm{m}^{3}$. Hal ini menunjukkan kelimpahan larva ikan pada musim timur lebih tinggi dibandingkan dengan musim peralihan. Akan tetapi pada ST5, ST7 dan ST8 pada musim timur lebih rendah dibandingkan pada musim peralihan.

Data lapangan yang diperoleh selama penelitian, tercatat nilai standar deviasi (SD) pada ST3, ST4 dan ST9 berkisar antara 0,090,24 menunjukkan nilai tersebut memiliki selisih jauh berbeda dibandingkan pada ST1, ST2, ST5, ST6, ST7 dan ST8 antara 0,010,04 dengan selisih tidak jauh berbeda (Gambar 2).

Perbedaan fluktuasi tinggi rendahnya kelimpahan larva ikan pada musim timur (Juni 2017) dan musim peralihan (September 2017) diduga parameter kondisi lingkungan perairan yang diperoleh selama penelitian berbeda terutama parameter arus perairan. Hal ini sesuai dengan pernyataan [33] kualitas air menentukan keberadaan, kelangsungan hidup dan kelimpahan larva ikan pada habitatnya. Selain itu, kecepatan arus perairan merupakan faktor utama perubahan kelimpahan dan distribusi pada setiap organisme akuatik dalam suatu habitat [34].

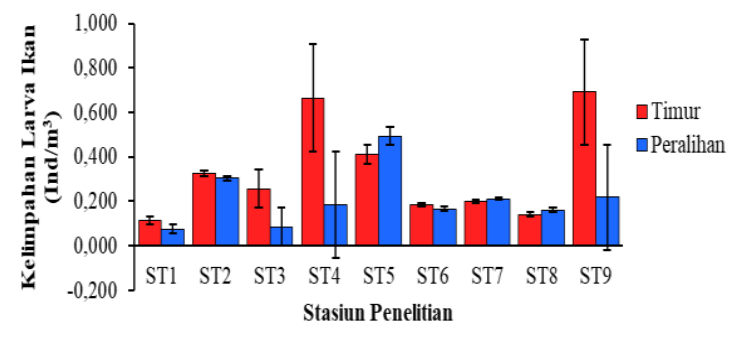

Gambar 2. Fluktuasi kelimpahan dan sebaran larva ikan di perairan pesisir Lampung Timur

Nilai kecepatan arus perairan tercatat pada musim timur berkisar antara 1,15-2,73 $\mathrm{m} / \mathrm{s}$ dan pada musim peralihan antara 0,68 $1,68 \mathrm{~m} / \mathrm{s}$ (Tabel 2). Hal ini menunjukkan kecepatan arus perairan pada musim timur tergolong arus perairan sangat cepat sedangkan pada musim peralihan tergolong arus perairan cepat hingga sangat cepat. Penggolongan kecepatan arus lambat berkisar antara $0-0,25 \mathrm{~m} / \mathrm{s}$, kecepatan arus sedang berkisar antara $0,25-0,50 \mathrm{~m} / \mathrm{s}$, kecepatan arus cepat berkisar antara $0,50-1 \mathrm{~m} / \mathrm{s}$ dan kecepatan arus sangat cepat diatas $1 \mathrm{~m} / \mathrm{s}$ [35].

Sementara itu, kecenderungan pada ST3 $\left(0,343 \mathrm{ind} / \mathrm{m}^{3}\right)$, ST4 $\left(0,850 \mathrm{ind} / \mathrm{m}^{3}\right)$ dan ST9 $\left(0,911 \mathrm{ind} / \mathrm{m}^{3}\right)$ yang terletak di sektor perairan pinggir menunjukkan perbedaan kelimpahan larva ikan pada kedua musim. Menurut [36] keberadaan larva ikan dan juwana di perairan estuari menunjukkan peran fungsional perairan estuari sebagai daerah pemijahan, pembesaran, perlidungan dan lumbung makanan.

\section{Komposisi Larva Ikan}

Identifikasi jenis famili larva berdasarkan pengukuran secara morfometrik tercatat 81 jenis famili larva ikan yang ditemukan. Dari semua jenis famili larva ikan teridentifikasi, terdapat 10 famili larva yang dominan baik pada musim timur (Juni 2017) dan musim peralihan (September 2017).

Komposisi larva berdasarkan musim, pada musim timur jenis famili larva ikan persentase terbanyak adalah Famili Mullidae (13\%) dan persentase yang paling sedikit adalah Famili Carangidae (1\%) sedangkan pada musim peralihan persentase terbanyak adalah Famili Pegasidae (19\%) dan persentase terendah adalah Famili Blenniidae (1\%) (Gambar 3A dan 3B). 
Adapun jenis famili larva ikan dengan persentase jumlah terbanyak dengan sebaran yang luas adalah Famili Gobiidae yang ditemukan pada periode kedua musim selama penelitian (Gambar 3C). Identifikasi larva ikan hanya dapat dilakukan hingga pada tingkat famili.

A.

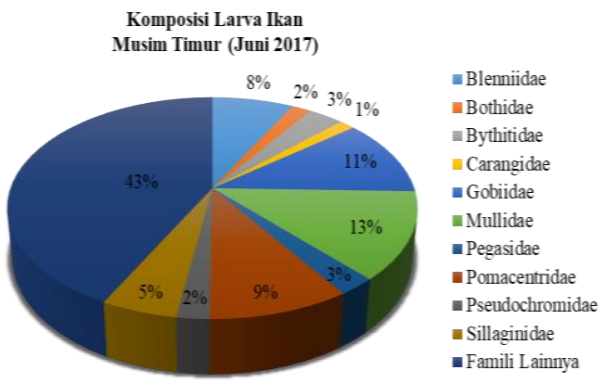

B.

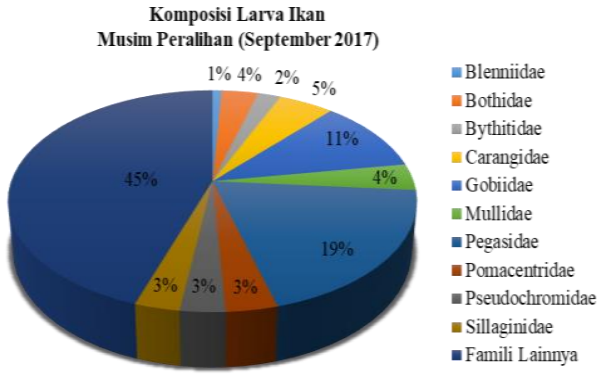

C.

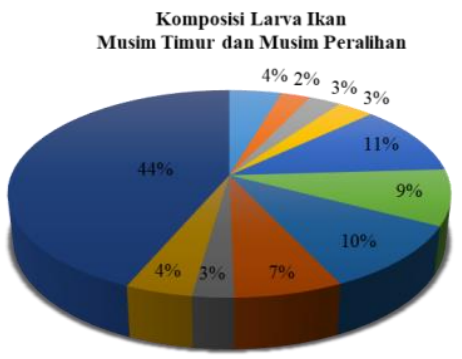

= Blenniidae

=Bothidae

$=$ Bythitidae

Carangidae

= Gobiidae

Mullidae

- Pegasidae

- Pomacentridae

- Pseudochromidae

- Sillaginidae

- Famili Lainnya

Gambar 3. Komposisi Larva Ikan di perairan pesisir Lampung Timur

Pada periode kedua musim tercatat Famili Mullidae dan Pegasidae merupakan persentase terbesar sedangkan Famili Carangidae dan Bleniidae dengan persentase terendah (Gambar 3A dan 3B). Hal ini sesuai dengan pernyataan $[37 ; 38]$ jenis Famili Mullidae dan Famili Pegasidae umumnya mendiami daerah substrat berpasir sedangkan Famili Carangidae dan Blenniidae mendiami daerah berbatu (terumbu karang) [39; 40]. Hal ini membuktikan perairan pesisir Lampung Timur merupakan daerah yang sesuai untuk Famili Mullidae dan Pegasidae untuk kelangsungan hidupnya. Namun, salah satu terjadinya perbedaan komposisi larva ikan di perairan sangat bergantung ketersediaan makanan secara alamiah di perairan. Makanan yang dimakan oleh larva tentunnya berkaitan dengan ketersediaannya di perairan [41].

Hasil samping yang dilakukan (Gambar 3C), tercatat Famili Gobiidae merupakan penyumbang terbesar dari seluruh total tangkapan pada kedua musim. Famili jenis ini bersifat amfidromus [42] dan dikenal mendiami daerah perairan estuari, memiliki sebaran yang luas memijah sepanjang waktu dan dapat mentolerir terhadap kondisi lingkungan perairan yang bisa saja dapat berubah-ubah [21; 24] sedangkan famili lainnya jarang ditemukan sehingga tidak adanya kontribusi. Menurut [43] menyatakan bahwa $<0.02 \%$ dari total kelimpahan dapat mengacaukan definisi variabel utama.

Sementara itu, berdasarkan tingkatan tahap stadia larva ikan persentase tahap flexion lebih tinggi dibandingkan tahap preflexion dan post-flexion.

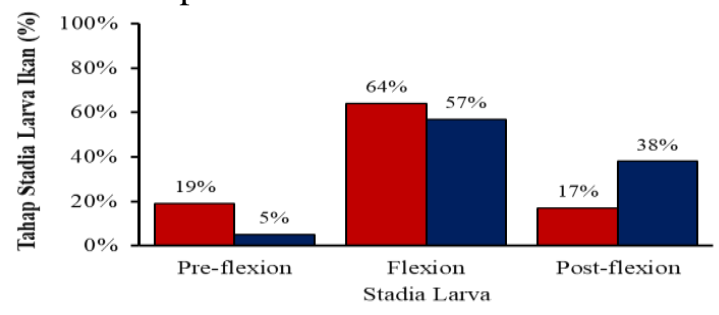

Gambar 4. Tahap stadia larva ikan

Besarnya persentase tahap flexion dibandingkan pre-flexion dan post-flexion mendeskripsikan larva ikan memerlukan habitat yang sesuai untuk perkembangan sejak stadia larva hingga kebentuk ikan dewasa. Secara morfologis pada tahap flexion menandakan ciri khas larva ikan habisnya kuning telur dan perkembangan ekor sudah terbentuk namun belum sempurna sehingga sebagian besar larva ikan pada tahap flexion mampu berenang bergerak menuju habitat esensial untuk perkembangan dalam keadaan kemampuan terbatas $[44 ; 45]$. Adapun tahap post-flexion secara morfologis bentuk tubuh sempurna terutama perkembangan ekor sehingga larva ikan mampu menghindari predator dan mampu berenang berlawanan arus [46] sedangkan tahap pre-flexion perkembangan bentuk tubuh belum begitu sempurna serta aktivitas larva sangat terbatas [45]. 


\section{Distribusi Stadia Larva Ikan}

Terdistribusinya banyaknya jumlah individu larva ikan pada sektor perairan pinggir (ST3; ST4; ST9) lebih tinggi dibandingkan sektor perairan tengah (ST2; ST5; ST8) dan perairan luar (ST1; ST6; ST7) mencerminkan ciri karakteristik habitat tidak sama diberbagai sektor perairan (Gambar 4) dan lokasi penelitian dengan jarak tertentu mengrefleksikan faktor kondisi lingkungan perairan secara tidak langsung sehingga berpengaruh terhadap distribusi larva ikan di perairan (Gambar 1). Menurut [47] Sebagian besar ikan laut pada tahap stadia larva, juvenil dan juwana memiliki perbedaan habitat dalam siklus hidupnya. Selain itu, faktor utama lainnya yakni angin yang berpengaruh kuat terhadap penyebaran [48] dan musim dapat mempengaruhi pola pertumbuhan ikan yang berbeda [49].
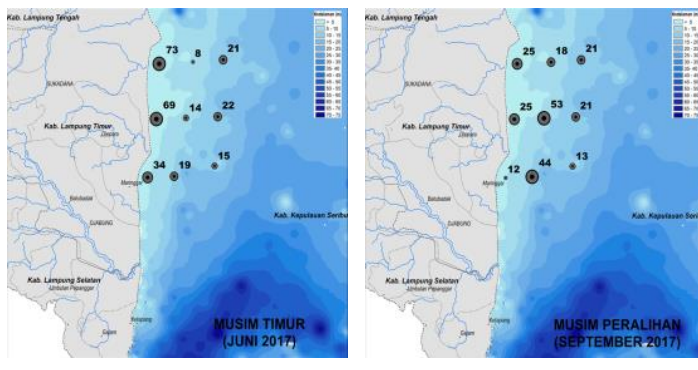

Gambar 5. Distribusi larva ikan di perairan pesisir Lampung Timur

\section{Kondisi Lingkungan Perairan}

Kondisi lingkungan perairan merupakan variabel secara tidak langsung dalam perkembangan ikan. Ikan pada tahap stadia merupakan fase kritis untuk memaksimalkan tingkat kelangsungan hidup dan berinteraksi terhadap kondisi lingkungan $[50 ; 18]$. Pola perubahan parameter kondisi lingkungan perairan menunjukkan fluktuasi nilai di pengaruhi oleh waktu (pagi hingga sore hari).

Pengukuran parameter fisika dan kimia merupakan gambaran kualitas air pada saat tertentu sedangkan parameter biologi sebagai indikator pemantau secara kontinyu di suatu perairan. Hasil pengukuran parameter kondisi lingkungan di perairan pesisir Lampung Timur disajikan pada Tabel 2
Tabel 2. Nilai kondisi lingkungan perairan pesisir Lampung Timur (parameter fisika)

\begin{tabular}{ccccccccc}
\hline & \multicolumn{8}{c}{ Parameter Fisika } \\
\cline { 2 - 9 } ST & $\begin{array}{c}\text { Arus } \\
(\mathbf{m} / \mathbf{s})\end{array}$ & \multicolumn{2}{c}{$\begin{array}{c}\text { Kecerahan } \\
(\mathbf{m g} / \mathbf{l})\end{array}$} & \multicolumn{2}{c}{$\begin{array}{c}\text { Kekeruhan } \\
(\mathbf{N T U})\end{array}$} & \multicolumn{2}{c}{$\begin{array}{c}\text { Suhu } \\
\left({ }^{\circ} \mathbf{C}\right)\end{array}$} \\
\cline { 2 - 10 } & $\mathbf{T}$ & $\mathbf{P}$ & $\mathbf{T}$ & $\mathbf{P}$ & $\mathbf{T}$ & $\mathbf{P}$ & $\mathbf{T}$ & $\mathbf{P}$ \\
\hline 1 & 1,45 & 1,68 & 0,26 & 0,36 & 1,1 & 0,3 & 30,0 & 29,2 \\
2 & 1,15 & 1,39 & 0,47 & 0,36 & 2,7 & 0,7 & 29,8 & 29,3 \\
3 & 1,98 & 0,68 & 1,22 & 0,55 & 4,0 & 4,2 & 30,2 & 29,9 \\
4 & 1,49 & 1,27 & 1,28 & 0,74 & 4,3 & 1,6 & 29,8 & 29,8 \\
5 & 1,41 & 1,16 & 0,98 & 0,48 & 1,7 & 0,9 & 30,1 & 29,7 \\
6 & 1,84 & 0,73 & 0,28 & 0,29 & 1,4 & 0,8 & 30,2 & 29,2 \\
7 & 2,73 & 1,43 & 0,54 & 0,32 & 2,4 & 0,7 & 30,0 & 29,7 \\
8 & 1,55 & 1,61 & 1,04 & 0,55 & 3,2 & 1,3 & 30,0 & 30,0 \\
9 & 2,27 & 0,99 & 1,49 & 0,67 & 2,5 & 1,6 & 29,8 & 30,0 \\
\hline
\end{tabular}

\section{Kecepatan Arus}

Hasil pengukuran kecepatan arus menunjukkan pada musim timur berkisar antara $1,15-2,73 \mathrm{~m} / \mathrm{s}$ (arus perairan sangat cepat) dan musim perlihan antara 0,68-1,68 $\mathrm{m} / \mathrm{s}$ (arus perairan cepat hingga sangat cepat). Penggolongan kecepatan arus lambat berkisar antara $0-0,25 \mathrm{~m} / \mathrm{s}$, kecepatan arus sedang berkisar antara $0,25-0,50 \mathrm{~m} / \mathrm{s}$, kecepatan arus cepat berkisar antara $0,50-1 \mathrm{~m} / \mathrm{s}$ dan kecepatan arus sangat cepat diatas $1 \mathrm{~m} / \mathrm{s}$ [35].

\section{Suhu, Salinitas dan pH}

Selama penelitian berlangsung kisaran parameter suhu, salinitas dan $\mathrm{pH}$ masingmasing antara $29,2-30,2{ }^{\circ} \mathrm{C}, 29,7-32,8$ psu dan 6,4-8,2. Nilai tersebut menunjukkan keadaan kisaran yang optimal bagi kelangsungan hidup dan pertumbuhan larva ikan (Tabel 2 dan Tabel 3). Beberapa hasil penelitian nilai kisaran optimal suhu $28-32{ }^{\circ} \mathrm{C}$ [51] salinitas di Indonesia 28-33 psu [52] dan pH ideal 7-8,5 [53]. Akan tetapi parameter pH pada ST3 di musim timur tercatat 6,4 . Nilai ini masih dikategorikan dalam kisaran optimal. Hasil penelitian [54] menyatakan bahwa ikan cupang (Betta splendens Regan) masih mendukung kehidupan kisaran antara pH 5,5-6,5.

\section{Kecerahan dan Kekeruhan}

Kecerahan merupakan gambaran intensitas cahaya yang masuk kedalam perairan sedangkan kekeruhan adalah keadaan terbalik dari kecerahan perairan. Selama penelitian nilai kisaran parameter kecerahan antara 0,3-1,5 $\mathrm{mg} / \mathrm{l}$ sedangkan kekeruhan antara 0,3-4,3 NTU. Kepmen LH No 5 tahun 
2004 standar baku mutu kekeruhan $<5$ NTU [55].

\section{Fitoplankton dan Zooplankton}

Fitoplankton dan Zooplankton secara umum dikenal sebagai plankton (jasad renik) yang terdapat di setiap perairan. Parameter fitoplankton berkisar antara 407,54-1748,55 $\mathrm{sel} / \mathrm{m}^{3}$ sedangkan zooplankton $41,31-234,25$ ind $/ \mathrm{m}^{3}$. Nilai plankton menunjukkan terdistribusinya sumber makanan larva ikan pada setiap stasiun penelitian. Konektivitas plankton terhadap larva ikan sebagai dasar rantai makanan untuk kelangsungan hidup. Selain itu, terjadinya fluktuasi nilai yang diperoleh selama penelitian berlangsung disebabkan perbedaan waktu pengukuran kondisi lingkungan perairan [56].

Tabel 3. Nilai kondisi lingkungan perairan pesisir Lampung Timur (parameter fisika dankimia)

\begin{tabular}{|c|c|c|c|c|c|c|c|c|}
\hline \multirow{3}{*}{ ST } & \multicolumn{5}{|c|}{ Parameter Kimia } & \multicolumn{3}{|c|}{ Parameter Biologi } \\
\hline & \multicolumn{2}{|c|}{ pH } & \multicolumn{2}{|c|}{$\begin{array}{c}\text { Salinitas } \\
\text { (PSU) }\end{array}$} & \multicolumn{2}{|c|}{$\begin{array}{l}\text { Fitoplankton } \\
\left(1000 \mathrm{sel} / \mathrm{m}^{3}\right)\end{array}$} & \multicolumn{2}{|c|}{$\begin{array}{c}\text { Zooplankton } \\
\text { (ind } / \mathbf{m}^{3} \text { ) }\end{array}$} \\
\hline & $\mathbf{T}$ & $\mathbf{P}$ & $\mathbf{T}$ & $\mathbf{P}$ & $\mathbf{T}$ & $\mathbf{P}$ & $\mathbf{T}$ & $\mathbf{P}$ \\
\hline 1 & 7,6 & 7,6 & 32,8 & 32,3 & 407,54 & 80,84 & 2020,60 & 330,90 \\
\hline 2 & 7,2 & 7,0 & 32,3 & 32,1 & 588,82 & 90,14 & 8110,09 & 166,08 \\
\hline 3 & 6,4 & 7,1 & 29,8 & 31,5 & 655,33 & 234,25 & 24766,85 & 644,18 \\
\hline 4 & 8,0 & 7,6 & 29,7 & 31,1 & 766,93 & 198,14 & 6669,50 & 0,00 \\
\hline 5 & 8,0 & 7,5 & 30,8 & 31,9 & 1111,17 & 119,71 & 4529,37 & 317,06 \\
\hline 6 & 7,9 & 7,6 & 32,6 & 31,7 & 768,79 & 203,63 & 3862,55 & 179,29 \\
\hline 7 & 8,1 & 8,2 & 32,4 & 31,7 & 783,90 & 82,24 & 11164,90 & 0,00 \\
\hline 8 & 8,1 & 8,0 & 31,4 & 32,2 & 1748,55 & 41,31 & 9964,61 & 539,75 \\
\hline 9 & 8,1 & 8,0 & 30,1 & 31,7 & 459,71 & 138,04 & 5661,71 & 169,85 \\
\hline
\end{tabular}

\section{Pengaruh Kondisi Lingkungan Perairan terhadap Kelimpahan dan Distribusi Larva Ikan}

\section{Cannonical Corespodence Analysis} (CCA) merupakan analisis multivariat dalam mempelajari hubungan antara dua variabel atau lebih dengan memperagakan baris dan kolom [57]. Hasil dari analisis korespodensi memperlihatkan dimensi terbaik untuk mempresentasikan data yang berupa peta persepsi (Tabel 4 dan Gambar 6).

Tabel 4. Nilai kontigensi hasil cannonical corespodence analysis (CCA) pada musim timur dan musim peralihan

\begin{tabular}{ccc}
\hline \multicolumn{3}{c}{ Musim Timur } \\
\hline Axis & Eigenvalue & $\%$ \\
\hline 1 & 0,34501 & 43,17 \\
2 & 0,27173 & 34 \\
3 & 0,13387 & 16,75
\end{tabular}

\begin{tabular}{cccc}
\hline & \multicolumn{2}{l}{ Musim Peralihan } & \multicolumn{1}{c}{ K } \\
\hline Axis & Eigenvalue & \multicolumn{2}{c}{$\%$} \\
\hline 1 & 0,42789 & 42,67 & \\
2 & 0,2731 & 27,24 & p \\
3 & 0,13627 & 13,59 & sek
\end{tabular}

A.
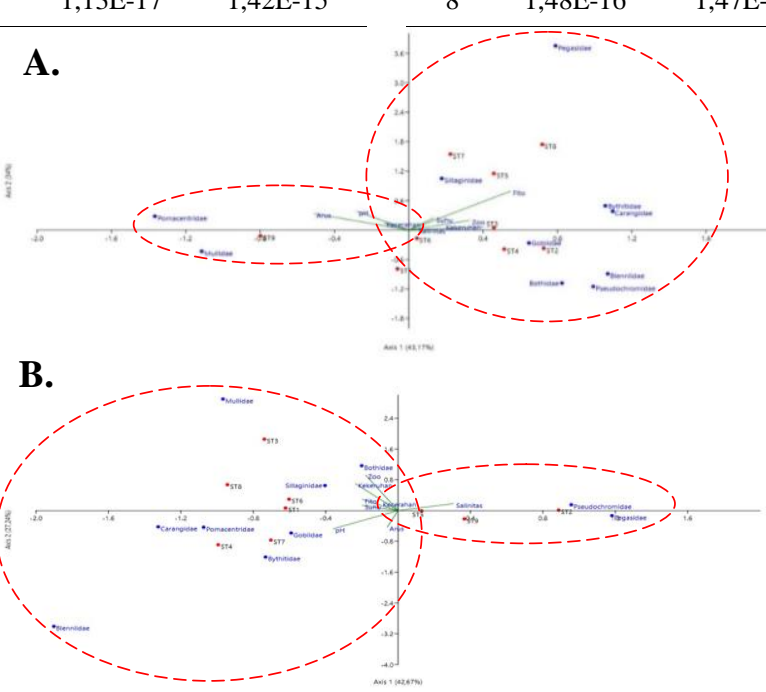

Gambar 6. Metode pendekatan multivirat

Hasil pengolahan data cannonical correspondence analysis (CCA) (Gambar 5) menunjukkan bahwa parameter kecerahan membentuk proyeksi titik sedangkan parameter kondisi lingkungan perairan lainnya membentuk proyeksi vektor terhadap kedua musim. Hal tersebut menunjukkan pada musim timur jenis famili larva ikan antara lain Blennidae, Bothidae, Bythitidae, Carangidae, Gobiidae, Sillaginidae, Pegasidae dan Pseudochromidae berkolerasi terhadap parameter Salinitas, suhu, kekeruhan, fitoplankton dan zooplankton dan parameter arus dan $\mathrm{pH}$ berkolerasi terhadap Famili Mullidae sedangkan pada musim peralihan (September 2017) jenis famili larva ikan Pseudochromidae dan Pegasidae berkolerasi terhadap parameter salinitas dan jenis famili larva ikan antara lain Blennidae, Bothidae, Bythitidae, Carangidae, Gobiidae, Mullidae, Pomacentridae, dan Sillaginidae berkolerasi terhadap parameter arus, suhu, kekeruhan, $\mathrm{pH}$, fitoplankton dan zooplankton.

\section{KESIMPULAN}

Kelimpahan dan distribusi larva ikan di perairan pesisir Lampung Timur di ketiga sektor perairan memiliki proporsionalitas terhadap parameter kondisi lingkungan 
perairan terutama parameter arus dan perbedaan periode musim. Semakin mendekati perairan pinggir menunjukkan semakin tinggi larva ikan yang tertangkap sedangkan semakin jauh dari perairan pinggir maka jumlah larva ikan yang tertangkap semakin sedikit.

\section{DAFTAR PUSTAKA}

[1] J. I. Pariwono, "Kondisi Oseanografi Perairan Pesisir Lampung," CRMP, Jakarta. 1999.

[2] Zairion, "Pengelolaan berkelanjutan perikanan rajungan (portunus pelagicus) di Lampung Timur," IPB. 2015

[3] E. P. Odum, "Dasar-Dasar Ekologi," Gadjah Mada University Press, Yogyakarta. 1993.

[4] F. Yuliani, S.Z. Musthofa, T. Kardini, dan D. Elfidasari, "Perkembangan larva ikan rainbow boesemani (Melanotaenia boesemani): Tahap pembentukan sirip dan pembelokan tulang ekor," J. World. Aquacult. Soc., vol. 2, no. 2, hal. 100104, Nov 2013.

[5] H. Effendi, "Telaah Kualitas Air," Kanisius 2003.

[6] K. Romimohtarto, dan S. Juwana, "Biologi Laut: Ilmu Pengetahuan tentang Biota Laut," Pusat Penelitian dan Pengembangan Oseanologi-LIPI, Jakarta 1999.

[7] D. T. Sulistyowati, Sarah, dan H. Arfah. "Organogenesis dan Perkembangan Awal Ikan Corydoras panda," JAI., vol. 4, no. 1, hal. 62-68, 2005.

[8] A. H. Rojo-Cebreros, I. L. Castro, dan M. J. M. Brown, "Immunostimulation and trained immunity in marine fish larvae," Fish. Shellfish. Immunol., vol. 18, Mei 2018.
[9] N.D.D. Barth, K.W. Shertzer, dan R.N.M. Ahrens, "Indices of abudance in the Gulf of Mexico reef fish complex a comparative approach using spatial data from vessel monitoring systems", Fish. Res., vol. 198, hal. 1-13, Okt 2018.

[10] I. R. Bradbury, dan P. V. R. Snelgrove, "Contrasting larval transport in demersal fish and benthic invertebrates: the roles of behavior and advective processes in determining spatial pattern", Can. J. Fish. Aquatic. Sci., vol. 58, hal. 811-823, Jan 2001.

[11] G. Gawarkiewicz, S. Monismith, dan J. Largier, "Observing larval transport processes affecting population connectivity progress and challenges", Oceanography., vol. 20, no. 3, hal. 4053, Sep 2007.

[12] J. Pineda, J. A. Hare, dan S. Sponaugle, "Larval transport and dispersal in the Coastal Ocean and consequences for population connectivity", Oceanography., vol. 20, no. 3, hal. 2239, Sep 2007.

[13] A. Sabates, dan M. Olivar, "Variation of larval fish distributions associated with variability in the location of a shelf-slope front", Mar. Ecol. Prog. Ser, vol. 135, hal. 11-20, Mei 1996.

[14] R. G. Lough, dan J. P. Manning, "Tidal-front entrainment and retention of fish larvae on the southern flank of George Bank". Deep-Sea Research II, vol. 48, hal. 631-644, Feb 2001.

15] O. Lee, R. D. M. Nash, dan B. S. Danilowicz, "Small scale spatio temporal variability in ichthyoplankton and zooplankton distribution in relation to a tidal-mixing front in the Irish Sea". ICES J. Mar. Sci., vol. 62, hal. 10211036, Apr 2005.

[16] P. B. Moyle, dan J. J. Cech, "Fisheries: an Introduction to Ichthyology". Prentice Hall, Amerika Serikat, 1988. 
[17] R. D. Brodeur, dan W. C. Rugen, "Diel vertical distribution of ichthyoplankton in the northern Gulf of Alaska". Fish. Bul., vol. 92, hal. 223-235, Jan 1994.

[18] N. Anwar, "Karakteristik fisika kimia perairan dan kaitannya dengan distribusi serta kelimpahan larva ikan di Teluk Palabuhan Ratu," IPB, 2008.

[19] M. A. Bahara, "Distribusi spasial dan temporal larva ikan di perairan Pulau Abang Galang Baru Batam Provinsi Kepulauan Riau," IPB, 2008.

[20] O. T. S. Ongkers, M. Boer, I. Muchsin, S. Sukimin, dan K. Praptokardiyo, "Sebaran spasio-temporal ikan yang tertangkap dengan jaring Pantai di Perairan Teluk Ambon bagian dalam," JII., vol. 9, no. 2, hal. 139-151, Okt 2009.

[21] A. Suryandari, "Komposisi, kelimpahan dan distribusi larva ika pada estuaria Pelawangan Timur segara anakan, Cilacap," IPB, 2012.

[22] E. Prianto, S. Nurdawaty, dan M. M. Kamal, "Distribusi, kelimpahan dan variasi ukuran larva ikan di estuari Sungai Musi," BAWAL., vol. 5, no. 2, hal. 73-79, Mei 2013.

[23] K. Amri, A. A. Mutoharoh, dan D. Ernaningsih, "Sebaran larva ikan dan kaitannya dengan kondisi oseanografi Laut Sulawesi," J. Lit. Perikan. Ind., vol. 21, no. 2, hal. 103-114, Jun 2015.

[24] A. S. Nastiti, M. R. A. Putri, dan A. A. Sentosa "Komposisi dan kelimpahan larva ikan sebagai dasar pengelolaan sumberdaya ikan diteluk Cempi, Nusa Tenggara Barat," BAWAL., vol. 8, no. 3, hal. 137-146, Des 2016.

[25] S. Daryumi, A. Hutabarat, dan A. Ghofar, "Komposisi dan distribusi spasial larva ikan ekonomis penting di perairan estuari banjir kanal timur Kota Semarang," MAQUARES, vol. 5, no. 3, hal. 91-97, 2016.
[26] Saraswati, A. Solichin, A. Hartoko, dan S. R. Suharti, "Hubungan kerapatan lamun dengan kelimpahan larva ikan di Pulau Pramuka, Kepulauan Seribu Jakarta," MAQUARES., Vol. 5, no. 3, hal. 111-118, 2016.

[27] F. Simanullang, Djuwito, dan A. Ghofar, "Distribusi dan kelimpahan larva ikan pada ekosistem mangrove di desa pasar banggi Kabupaten Rembang," MAQUARES, vol. 5, no. 4, hal. 199-208, 2016.

[28] A. F. Erzad, S. Hutabarat, dan M. X. Muskananfola, "Distribusi dan kelimpahan larva ikan di kawasan perairan pantai dukuh bedono Kecamatan Sayung Kabupaten Demak," MAQUARES., vol. 6, no. 4, hal. 339-347, 2017.

[29] I. Jatmiko, F. Rochman, G. L. Arnenda, "Distribution and abudance of fish larvae in South of Alas Strait, West Nusa Tenggara," ILMU KELAUTAN., vol. 23, no. 2, hal. 87-92, 2018.

[30] D. D. Kembaren, "Determinasi daerah pemijahan rajungan (Portunus pelagicus Linnaeus 1758) berdasarkan komposisi dan distribusi larva di perairan Lampung Timur," IPB, 2018.

[31] J. M. Leis, B. M. Carson-Ewart, "The larvae of Indo-Pacific coastal fishes: An identification guide to marine fish larvae," Brill Publishers., 2000.

[32] M. L. E. Fuentes, C. F. Coto, L. S. Anorve, dan F. Z. Garcia, "Vertical distribution of zooplankton biomass and ichtyoplankton density an annual cycle on the Continental Shelf of the Southern Gulf Of Mexico," Rev. Biol. Mar. Oceanogr., vol. 4, no. 2, hal. 477488, Aug 2009.

[33] C. E. Stouthamer dan M. B. Bain, "Quantifying larval fish habitat in Shoreline and shallow waters of the Tidal Hudson" in Section VII, Final Reports of the Tibor T. Polgar 
Fellowship Program in 2010. S. H. Fernald, D. J. Yozzo and H. Andreyko (eds.), 1-25, Mar 2012.

[34] Arshad et al., "Population Parameters of Planktonic Shrimp, Lucifer intermedius (Decapoda: Sergestidae) from Sungai Pulai Seagrass Area Johor, Peninsular Malaysia", SAINS MALAYS., vol. 39, no. 6, hal. 877-882, Des 2010.

[35] T. E. Y. Sari dan Usman, "Studi parameter fisika dan kimia daerah penangkapan ikan Perairan Selat Asam Kabupaten Kepulauan Meranti Provinsi Riau,” J. Perikanan dan Kelautan., vol. 17, no. 1, hal. 88-100, 2012.

[36] A. Zahid, C. P. H. Simanjuntak, M. F. Rahardjo dan Sulistiono, "Iktiofauna eksositem estuari Mayangan, Jawa Barat", JII., vol. 11, no. 1, hal. 77-85, Juni 2011.

[37] F. Uiblein, "Goatfishes (Mullidae) as indicators in tropical and temperate coastal habitat monitoring and management," Mar. Biol. Res., no. 3, hal. 275-288, Sept 2007.

[38] R. H. Kuiter, "The remarkable seamoths," Scuba Diver., vol. 3, no. 3, hal. 16-18, 1985.

[39] K. Wibowo, M. Abrar dan R. M. Siringoringo, "Status trofik ikan karang dan hubungan ikan herbivora dengan rekrutmen karang di perairan Pulau Pari, Teluk Jakarta," OLDI., vol. 1, no. 2, hal. 73-89, Jul 2016.

[40] A. L. Ooi dan V. C. Chong, "Larval fish assemblages in a tropical mangrove estuary and adjacent coastal water: Offshore-inshore flux of marine and estuarine species," Cont. Shelf. Res., vol. 31, hal 1599-1610, Jun 2011.

[41] M. I. Effendie, "Biologi Perikanan", Yayasan Pustakan Nusantara, Yogyakarta., hal. 163, 2002.
[42] R. M. McDowall, "On amphidromy, a distinct form of diadromy in aquatic organisms", FISH FISH J., vol. 8, hal. 1-13, Oct 2006.

[43] P. Pepin dan J. T. Anderson, "Scaledependent variations in the precision of larval fish abudance estimates: a study of Sebastes sp. On Flemish Cap," Can. J. Fish. Aquat. Sci., vol. 54, hal. 11111120, Jan 1997.

[44] G. S. Helfman, B. B. Collete, D. E. Facey dan B. W. Bowen, "The Diversity of Fishes Biology, Evolution and Ecology" Willey Blackwell Pubhlisers, New Jersey. 2009.

[45] W. Andriyanto dan M. Marzuqi, "Hubungan perkembangan morfologi dengan organ pencernaan larva kerapu bebek (Cromileptes altivelis) turunan ke-3 (F-3)," J. Fish. Sci., vol. 14, no. 1, hal, 46-56, 2012

[46] A. S. Chute dan J. T. Turner, "Plankton studies in Buzzards Bay, Massachusetts, USA. V. ichthyoplankton 1987 to 1993," Mar. Ecol. Prog. Ser., vol. 224, hal, 45-54, Dec 2001.

[47] Subiyanto, "Ecological Study of Flat Fishes, Especially on the Imigration of Larval and Juvenile Japanese Flounder (Paralichthys olivaceus) in The Yatsushiro Sea and Adjacent Waters, Japan". Disertation Graduate School of Marine science and Engineering., Nagasaki University, 1992.

[48] R. K. Cowen, "Larval dispersal and retention and consequences for population connectivity. In Coral Reef Fishes. Dynamics and Diversity in a Complex Ecosystem. (Ed. P. F. Sale.)", Elsevier Science., hal. 149-170, 2002.

[49] A. Anene, "Condition factor of four cichlid species of a man-made lake in Imo State, Southeastern Nigeria," Turk. J. Fish. Aquat. Sc., vol. 5, hal. 43-47, Sept 2005. 
[50] S. Zacharia dan V. S. Kakati, "Optimal salinity and temperature for early developmental stages of Penaeus merguiensis de man," Aquaculture., vol. 232, hal. 373-382, Jul 2004.

[51] M. G. H. Kordi dan A. B. Tancung, "Pengelolaan kualitas air dalam budidaya perairan," PT. Rhineka Cipta, Jakarta, hal. 1-210, Jun 2007.

[52] A. Nontji, "Laut nusantara," Djambatan, hal. 1-372, 2005

[53] T. A. Barus, "Pengantar limnologi studi tentang ekosistem air daratan," USU Press, 2004

[54] G. W. Dewantoro, "Fekunditas dan produksi larva pada ikan cupang (Betta splendes regan) yang berbeda umur dan pakan alaminya," JII., vol. 1, no. 2, hal. 49-52, 2001.

[55] KEPMEN, "Lingkungan hidup," Baku Mutu Air Laut., no. 5, 2004.

[56] A. Suriadarma, "Dampak beberapa parameter faktor fisik kimia terhadap kualitas lingkungan perairan wilayah pesisir karawang-Jawa Barat", Ris. Geo. Tam., vol. 21, no. 2, hal. 21-36, Jun 2011.

[57] M. Greenacre, "Correspondence analysis in practice", Chapman dan Hall/CRC, hal. 1-275, 1993. 